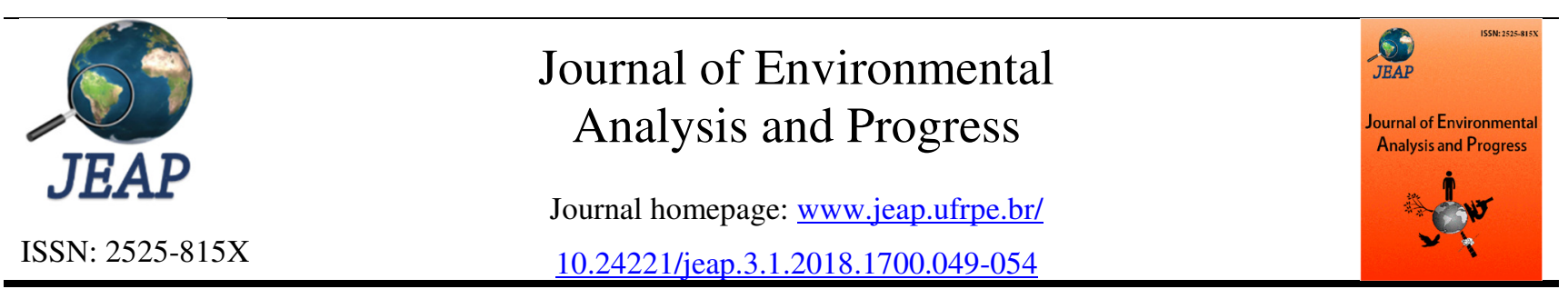

\title{
Qualitative analysis of the behavior of the seedlings of sugarcane of different varieties using the method of temporary immersion
}

\author{
Michelle Maria Perez Lott ${ }^{\mathrm{a}}$, Arthur Travassos de Queiroz Xavier ${ }^{\mathrm{a}}$, Áurea Alice Oliveira da Silva ${ }^{\mathrm{a}}$ \\ a Biofábrica Governador Miguel Arraes, Centro de Tecnologias Estratégicas do Nordeste-CETENE, Professor Luís \\ Freire, n. 01, Cidade Universitária, Recife, Pernambuco, Brasil. CEP: 50740-545. E-mail: \\ michelle.lott@cetene.gov.br, arthur.travassos@cetene.gov.br, aurea.oliveira@cetene.gov.br.
}

A R T I C LE IN F O

Received 10 Nov 2017

Accepted 02 Jan 2018

Published 22 Jan 2018

\begin{abstract}
A B S T R A C T
Sugarcane is a culture of high importance worldwide due to the fact it is the raw material needed to produce sugar, ethanol, and biomass, among other products. The micropropagation of seedlings in a lab generates superior production when compared to the conventional process of propagation in the field. Therefore, it is an alternative to producing healthy seedlings that present the same genetic load of the matrices. The micropropagation has an excessive cost of workforce used in the process. The System of Temporary Immersion (SIT) was created with the goal of solving this issue. At the bio-factory Governador Miguel Arraes of the Center of Strategic Technology of the Northeast (CETENE), this system consists of PET bottles of $5 \mathrm{~L}$ (Bioreactors-BITs), a group of hoses and two Millipore filters as well as automatic controllers. Within the BITs, it is possible to multiply a higher quantity of plants decreasing, this way, the time within the lab. The objective of this study was the qualitative analysis of the behavior of the System of Temporary Immersion using seedlings of different varieties of sugarcane. The methodology consisted of transferring the content of 1 or 3 pots, depending on the test, to the bioreactor with $200 \mathrm{ml}$ and $500 \mathrm{ml}$ of culture mean respectively. Where used two varieties of great interest to the Bio-factory. One of them, on the first pricking, presented a better response than the other, and days later the majority presented loss through contamination.
\end{abstract}

Keywords: Bioreactor, micropropagation, multiplication, Bio-factory, production.

\section{Introduction}

The production of sugarcane in Brazil stands out in a global context. According to the CONAB (2015), "Brazil is not only the biggest producer of sugarcane. It is also the first in the world regarding the production of sugar and ethanol, and conquers, more and more, the foreign market using biofuel as an energy alternative".

The numbers predicted by the MAPA (2017) for the exportation of products derived from sugarcane point to a favorable scenario for the production of this crop in the country, but according to the MAPA (2017 apud OECD-FAO, 2015) sugarcane plants are facing difficulties due to the lack of investment in the sugar-alcohol sector and climate-related adversities which result in reduced mean productivity. An alternative which aims to increase the productive capacity of the plants is micropropagation in large scale.

Plant micropropagation is a process with the goal of obtaining plants of certain phytosanitary quality, in which genetic material is identical to the material collected in the fields (Dutra et al., 2011). According to França (2016 apud Cidade et al., 2006), "Micropropagation offers valuable tools for spreading sugarcane since it is possible to produce healthy seedlings in large scale and reduced time and space." This process demands 6 to 8 months between the set up in a lab and the return to the field, but it can generate a substantially higher number of plants when compared to the conventional process of propagation.

The price of the seedling is relatively high in conventional micro-propagation, and this fact may be explained by the high cost of the workforce employed in the process (Teixeira, 2001). The workforce must be highly skilled and trained to achieve a high number of multiplications and low levels of contamination in the process to ensure the quality of the seedlings that will be delivered to the final customer. An alternative to conventional micropropagation is the system of temporary immersion. Many types 
were produced until reaching the model of EMBRAPA (2005).

One of the main products of the biofactory Governor Miguel Arraes of CETENE (Center of Strategic Technology of the Northeast) is the micro-propagated sugarcane. Considering the multiply the material collected from the field in the production lab, two methods were used: in vitro (or stationary) and through the System of Temporary Immersion (SIT or bioreactor). The SIT consists of two PET (Polyethylene terephthalate) bottles of $5 \mathrm{~L}$, a set of hoses and two Millipore filters of $0,22 \mu \mathrm{m}$, as well as automated controllers.

Once the bioreactors (BITs) are installed, there is an increase in productive capacity. It is because is possible to place more plants in a bioreactor than in the glass containers. Moreover, the plants have more space in the bioreactor to grow longer in size and multiply (EMBRAPA, 2005). The SIT needs to be enhanced so that plants can reach higher multiplication rates with assured phytosanitary quality. The question this experiment seeks to answer is: How do the seedlings of different varieties of sugarcane behave when placed in the System of Temporary Immersion?

The system of temporary immersion is a very relevant technology as regards the increase of productivity. For this reason, it is important to invest time and financial resources with the objective of achieving better results when utilizing the system, which will result in greater multiplication of the plant material.

Among the advantages of using the bioreactors in the process of conventional micropropagation, the EMBRAPA (2005) highlights the use of flasks with greater volume, greater uniformity of the plants, an increase in production - which leads to diminishing the time of cultivation, less gas and mechanic stress, better morphogenic response due to better cultivation conditions and constant gas exchange. Among the disadvantages, contamination may be mentioned, which causes the death of more plants when it occurs within the compartment compared to when micropropagation is used in vitro.

"Just like in traditional cultivation of plant tissues, some of the greater issues faced with the use of bioreactors are related to the contamination, oxidation, and hyperhydricity of explants. Contamination can be divided into two groups: endogenous contamination - a kind of contamination that is difficult to detect due to being systemic, normally caused by bacteria (pathogenic or not) and viruses - and exogenous contaminations - caused by microorganisms of the soil that can be found in the environment, as well as those that are part of the normal bacterial flora of the human body, which can be fungi or bacteria. In general, the control of both sorts of contamination can be achieved through the architectural planning of the workplace; through the knowledge of the origin and age of the matrix plants; through the environment and personal hygiene; and through the ability and technical preparation of the workers." (Bastos \& Ribeiro, 2008)

The general objective of this research was the qualitative analysis of the behavior of the system of temporary immersion using seedlings of sugarcane of different varieties.

\section{Material and Methods}

Initially, the seedlings were transferred from glass containers to the BIT, to analyze the development of the seedlings, to analyze the contamination within the BITs, to understand the difference of development of each studied variety in the SIT. After, qualitative methods were used to analyze the results obtained and get to know the research needs for the system's optimization

First, the seedlings were transferred from the in vitro methodology to the methodology of Temporary Immersion, with the goal of developing this project. The daily follow up of the different tests was done by two researchers (responsible for the control of processes and products and responsible for the planning and control of production) with the help of the assistants and production programmers who have proven experience in sugarcane micropropagation. Any change suffered by the material was registered through photos and weekly reports.

It is related to the qualitative analysis of the behavior of the sugarcane seedlings of two varieties, transferred from the pot to the bioreactor. The qualitative methodology was adopted, to establish protocols of micropropagation in bioreactor through quantitative experiments. "Qualitative research doesn't preoccupy itself with numerical representativeness, but with the deepening of the comprehension of a social group, of an organization, etc." (Silveira, 2009, p. 31).

Experiments in the System of Temporary Immersion were made, in which seedlings that were on the $4^{\text {th }}$ sub-cultivation in the in vitro methodology were transferred to the bioreactors with $200 \mathrm{~mL}$ and $500 \mathrm{~mL}$ of mean MS (Murashige \& Skoog, 1962), depending on the number of pots introduced in each BIT. The plants were directly transferred to the BIT without 
prickling, which means that they were not cut before the change of methodology.

The bioreactors were washed with water and detergent, sterilized with alcohol $70 \%(\mathrm{v} / \mathrm{v})$ and hypochlorite of sodium $(\mathrm{NaClO})$. It remained within the solution of hypochlorite of sodium and water for the maximum periods of one hour and three hours.

The varieties used were RB 863129 and B 8008 because there are few studies regarding their particularities about micropropagation within BITs. Each experiment was repeated five times, using two quantities of different pots in each BIT introduced (one and three pots). The quantity of mean is directly related to the quantity of the pot (one pot $-200 \mathrm{~mL}$ and three pots $-500 \mathrm{~mL}$ ); the other variables such as light (2000 to $3000 \mathrm{lux}$ ), time of sub-cultivation (15 days), temperature (24 to $26^{\circ} \mathrm{C}$ ), among others, were kept the same for all the experiments. Each bioreactor was named according to the number of pots and the variety of the plant.

The period of the experiment was one month, and every $15 \pm 5$ day a prickling of the plants that multiplied in the compartment took place.

Table 1. Qualitative tests of the Variety RB 86 3129. Font: Authors (2017).

Variety RB 863129

\begin{tabular}{|c|c|c|c|}
\hline Test & Number of pots & Subculture & Introduction date \\
\hline B 2.2 & \multirow{5}{*}{ 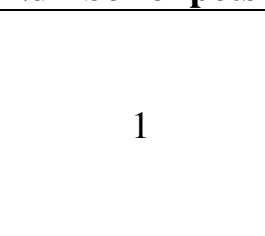 } & \multirow{10}{*}{$4^{\circ}$} & \multirow{10}{*}{ 27/09/2017 } \\
\hline B 2.3 & & & \\
\hline B 2.4 & & & \\
\hline B 2.5 & & & \\
\hline B 2.6 & & & \\
\hline B 3.2 & \multirow{5}{*}{3} & & \\
\hline B 3.3 & & & \\
\hline B 3.4 & & & \\
\hline B 3.5 & & & \\
\hline B 3.6 & & & \\
\hline
\end{tabular}

Table 2. Qualitative tests of variety B 8008. Font: Authors (2017).

\begin{tabular}{|c|c|c|c|}
\hline \multicolumn{4}{|c|}{ Variety B 8008} \\
\hline Test & Number of pots & Subculture & Introduction date \\
\hline B 4.2 & \multirow{5}{*}{1} & \multirow{15}{*}{$4^{\circ}$} & \multirow{15}{*}{ 27/09/2017 } \\
\hline B 4.3 & & & \\
\hline B 4.4 & & & \\
\hline B 4.5 & & & \\
\hline B 4.6 & & & \\
\hline B 5.2 & \multirow{10}{*}{3} & & \\
\hline B 5.3 & & & \\
\hline B 5.4 & & & \\
\hline B 5.5 & & & \\
\hline B 5.6 & & & \\
\hline $\begin{array}{l}\text { B } \\
5.4 .1\end{array}$ & & & \\
\hline B & & & \\
\hline 5.5 .1 & & & \\
\hline $\mathrm{B}$ & & & \\
\hline 5.6 .1 & & & \\
\hline
\end{tabular}

\section{Results}

A total of 20 tests were made with the varieties RB 863129 and B 8008. The tests were divided in the following manner: 10 of each variety studied. Both Tables (1 and 2) show the data related to each test made within the Lab of
Production at the Bio-factory Governador Miguel Arraes of CETENE. The terms used made more accessible to follow up each test since the first number indicates the variety used and the second number represents each repetition of the same experiment. 
The first prickling took place on the $11^{\text {th }}$ of October of 2017, 14 days after the introduction of these plants to the System of Temporary Immersion. The plants were on the $4^{\text {th }}$ subcultivation and after the cut went for the $5^{\text {th }}$ subcultivation. There was a great multiplication in each bioreactor. During this first cut, no contamination by bacteria or fungi was detected in the mean of culture, and the plants remained clean.

Within the bioreactors of the variety RB 863129 , in which one pot was put, the multiplication rate was 17 times, which means that one pot generated in average 17 plants after 14 days from the introduction. Within the BITs of the same variety in which three pots were inserted, the multiplication rate was 13 per pot, on average. Regarding the B 8008, in which one pot was put, the average multiplication rate was 16 . In those that three pots were inserted, the multiplication was 12 per pot, on average. In this first cut, it was already possible to notice a small difference between the studied varieties.
The variety RB 863129 presented a higher multiplication rate than B 8008 in both kinds of test. In this manner, it was the variety that most multiplied itself and adapted better to the new methodology used when compared to the other studied variety.

Two days after the prickling, in the tests called B2.4, B 2.5, B 3.4 and B 3.5 appeared signs of bacterial contamination. Already in B 3.2, after eight days of the prickling the recipient where the mean of the culture was started to foam, and the plants already showed signs of fungal contamination. Tests 4.4, 5.2, 5.3, and 5.6 also presented fungi spread through the plants after 12 days.

In Figure 1, the bioreactor of the Test B 3.5 was apparently without contamination (this photo was taken after the first prickling). In the Figure 2. the same test, but presenting fermentation on the plant and in the mean of culture, the particular process of fungus contamination.

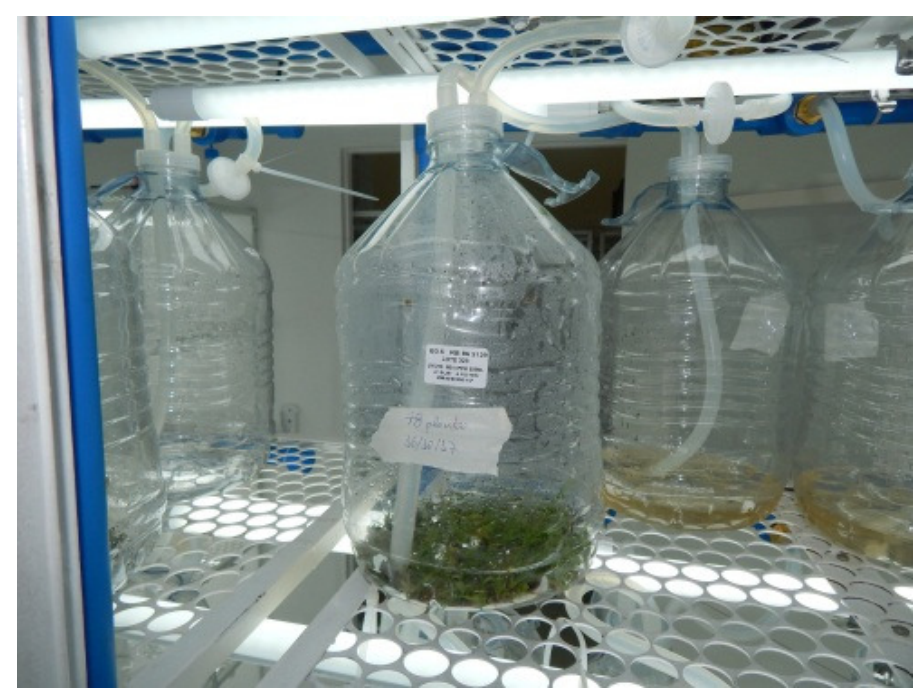

Figure 1. Bioreactor without contamination of the Test B 3.5. Font: Authors (2017).

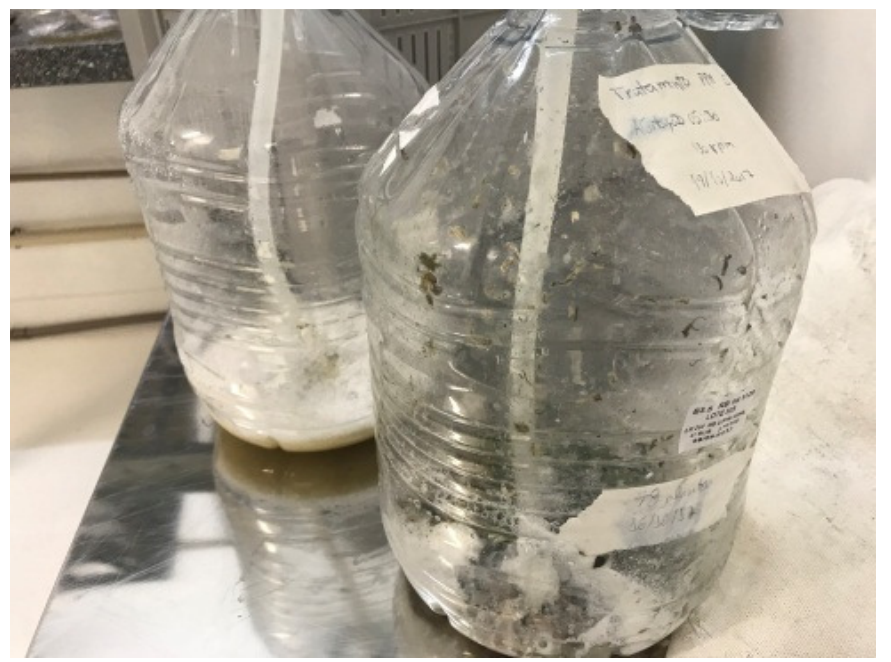

Figure 2. Bioreactor contaminated of the Test B 3.5. Font: Authors (2017). 
The contaminated bioreactors were discarded, and there were only five left of RB 86 3129 and 6 of B 8008 .

The second prickling happened on the $26^{\text {th }}$ of October of 2017, precisely 15 days after the first one. The bioreactors went from the $5^{\text {th }}$ subcultivation to the $6^{\text {th }}$. On this date it was observed that some bioreactors presented fungal contamination, which was; B 3.3, B 2.1 and B 5.4. For this reason, of the variety RB 863129 , there was prickling of only 3 BITs, and of the B 8008, there were five.

Test B 2.2 in the first prickling in a bioreactor gave 12 plants. As for the second prickling, it gave only 15 plants. The multiplication rate was 1,25 from the $5^{\text {th }}$ subcultivation to the $6^{\text {th }}$. This fact demonstrates a very low multiplication which can be explained due to the change in the compartment, a cut made during the prickling, and a mean of culture with less hormone than necessary for a high multiplication of this variety.

The remaining tests also didn't present many tillers from the $5^{\text {th }}$ sub-cultivation to the $6^{\text {th }}$. However, the plants which were able to multiply better were of the variety B 8008 . As an example of this fact, B 4.3 had 20 plants, and in the second prickling, it generated 100 plants.

The duration of the period under analysis was a month. The results demonstrated a better response regarding the multiplication of the seedlings of the variety RB 863129 compared to B 8008. No contamination was found in the BITs of either variety within the first 14 days. The quantity of the bioreactors contaminated after the first prickling is an important number since it is needed to analyze what happened to cause such great contamination (12 bioreactors). To better understands the system, it is necessary to analyze each factor quantitatively and verify the answers to generate protocols of micropropagation within the SIT.

All the contaminated bioreactors killed the plant, which eliminates the cause of contamination by endophytic fungi. The contamination was higher in the BITs of the variety RB 863129 after the cutting of the $5^{\text {th }}$ subcultivation to the $6^{\text {th }}$, which demonstrates that the seedlings of this variety are frailer compared to B 8008.

The variety RB 863129 was able to develop itself a lot better than the B 8008 before the prickling. The means of minimizing this contamination must be studied so that the plants continue multiplying extensively even after the cutting (as many as necessary). Considering this minimization, it is possible to produce healthy plants with less workforce employed, which would lead to the decrease of the total production cost of the process of micro-propagation.

Out of the 20 bioreactors introduced, only eight did not present contamination after one month and were able to multiply.

\section{Discussion}

The contamination observed in the bioreactors, where the tests for this research took place, is a challenge for the use of SIT. According to Medeiros (2011), "The main disadvantages of the use of bioreactors, in System of Temporary Immersion, have been the variation on the size of the seedlings formed, which leads to a lack of uniformity in acclimatizing, the microbial contamination, which can affect thousands of plants in a single recipient, there recalcitrance and hyperhydricity of explants".

The contaminating agents can be present in the compression process, in which the lubricating oil and the solid particles generated in the deterioration of the mobile pieces present the possibility of contaminating the compressed air which passes through the system (Costa, 2013).

Ribeiro \& Bastos (2008) put in evidence the importance of some variables related to the SIT which must be studied for an improvement of the system. "Variables such as the type of the bioreactor, the volume and the composition of the mean of the culture, the flux of air, (...) and the mean used to control the concentration of dissolved oxygen, $\mathrm{CO}^{2}$ and $\mathrm{pH}$ are of great importance for the adequate development of the culture and vary according to the plant species which will be used."

\section{Conclusion}

The SIT is important in a Bio-factory due to the increase in productivity caused by its use. It is necessary to invest in research with the goal of continuous improvement of the system.

The qualitative analysis of the System of Temporary Immersion using seedlings of sugarcane of the varieties RB 863129 , and B 8008 supplied confirmed the need for a quantitative evaluation of some parameters of the system to minimize the contamination. The contamination started right after the first prickling in the bioreactor; therefore, it is important to carefully analyze the prickling process and the post-prickling to understand the reason of this occurrence, keeping in mind that there was no contamination in any of the BITs before the prickling.

The causal factors of the fungal contamination are incorrect manipulation, 
inefficient sterilization, failures in the system (rupture), and endophytic microorganisms (which can contaminate without killing the plant).

\section{Acknowledgements}

The authors thank the Bio-factory, through the assistants (Pauliana Gomes, Taciana Lino, Thaiza Andrade, Jaqueline Herculano, Flávia Herculano, Wilma Karla, Bruno Arruda, Gilson Costa, Gilmar Ferreira, Leandro Alves); production programmers (Elisangela Cabral, Diógenes Alexandre), general services (Benedito Silva), receptionist (Dyanne Nunes) for helping with the tasks: transference of the seedlings to the BITs, prickling and weekly monitoring; sharing experience with the micro-propagation. To the researchers (Áurea Oliveira, Arthur Travassos, Diógenes Nascimento) for contributing substantially with ideas, the revision of the article, and for contributing to the monitoring of the whole process. To the National Council of Research and Development (CNPq) for the scholarship in the modality Program of Institutional Capacitation (PCI-DD). To the Center of Strategic Technology of the Northeast (CETENE) for offering all the necessary structure for the tests.

\section{References}

MELO, A. DE S.; SAMPAIO, Y. S. B. 2016. Uma Nota Sobre o Impacto do Preço do Açúcar, do Etanol e da Gasolina na Produção do Setor Sucroalcooleiro. Revista Brasileira de Economia, v. 70, n. 1, p. 61-69.

$\begin{array}{llr}\text { COMPANHIA } & \text { NACIONAL } & \text { DE } \\ \text { ABASTECIMENTO. } & \text { 2017. Indicadores } & \text { da } \\ \text { Agropecuária, ano XXVI, n. 9, p. 01-120. } & \end{array}$

COMPANHIA NACIONAL DE
ABASTECIMENTO. 2017. Acompanhamento da safra brasileira de cana de açúcar, safra 2016/2017, Companhia Nacional de Abastecimento, v. 3, n.4, p. 01-82.

RIBEIRO, J. M.; BASTOS, D. C. 2008. Biorreatores: aspectos gerais e sua utilização para cultura de tecidos vegetais. Embrapa SemiáridoDocumentos (INFOTECA-E).

JUNGHANS, T. G.; SOUZA, A. DA S. 2013. Aspectos práticos da micropropagação de plantas. Embrapa Mandioca e Fruticultura Tropical, Segunda Edição. 407p.

COSTA, D. A. et al. 2012. Aspectos fisiológicos da cana-de-açúcar sob o cultivo in vitro em diferentes microambientes. Tese de Doutorado. Universidade Federal Rural de Pernambuco. Recife, Pernambuco, Brasil. 82p.

MEDEIROS, E. C. DE. 2011. Aspectos bioquímicos e fisiológicos da palma forrageira Opuntia stricta Hawsob distintos sistemas de cultivo in vitro. Dissertação de mestrado. Universidade Federal Rural de Pernambuco. Recife, Pernambuco, Brasil. 24p.

AGÊNCIA EMBRAPA DE INFORMAÇÃO TECNOLÓGICA. Embrapa. Disponível em: http://www.agencia.cnptia.embrapa.br/gestor/cana -de-

acucar/arvore/CONTAG01_59_22122006154840.

html. Acesso em: 25 de outubro, 2017.

\section{ESTATÍSTICAS E DADOS BÁSICOS DE ECONOMIA AGRÍCOLA. Ministério da Agricultura, Pecuária e Abastecimento. Disponível em: http://www.agricultura.gov.br/assuntos/politica- agricola/todas-publicacoes-de-politica- agricola/estatisticas-e-dados-basicos-de- economia-agricola/pasta-de-julho-2017.pdf/view. Acesso em: 10 de outubro, 2017.}

PRODUÇÃO DE CANA DE AÇÚCAR NO BRASIL (E NO MUNDO). Nova Cana. Disponível em: https://www.novacana.com/canade-acucar/producao-cana-de-acucar-brasil-emundo/\#producao-pelo-mundo. Acesso em: 25 de setembro, 2017.

SAFRA 2017/2018 DE CANA-DE-AÇÚCAR. Governo do Brasil. Disponível em: http://www.brasil.gov.br/economia-eemprego/2017/04/safra-2017-2018-de-cana-deacucar-deve-ser-de-647-milhoes-de-toneladas. Acesso em: 23 de outubro, 2017.

COSTA, D. A. 2013. Biorreatores de Imersão Temporária: Manipulação e Funcionamento. Disponível em: https://pt.scribd.com/doc/68059888/biorreatoresna-micropropagacao-de-plantas. Acesso em: 07 de outubro, 2017.

DONINI, L. P.; MAYER, K. C. DE A.; ZACARIAS, F. M.; SILVA, N. D. G. DA.; VITÓRIA, J. M.; SILVA, S. D. DOS A. E; DUTRA, L. F. 2012. Produção de mudas de cana de açúcar (Saccharum officinarum L.) Micropropagadas. Simpósio Estadual de Agroenergia, Porto Alegre-RS, Brasil, EMBRAPA. 